\title{
Antimicrobial Resistance Genes in Animal Manure, Manure-Amended and Nonanthropogenically Impacted Soils in Spain
}

\author{
Fernando Esperón*, Carlos Sacristán, Matilde Carballo, Ana de la Torre \\ Grupo de Epidemiología y Sanidad Ambiental, Centro de Investigación en Sanidad Animal (INIA-CISA), Valdeolmos, Spain \\ Email: *esperon@inia.es
}

How to cite this paper: Esperón, F., Sacristán, C., Carballo, M. and de la Torre, A. (2018) Antimicrobial Resistance Genes in Animal Manure, Manure-Amended and Nonanthropogenically Impacted Soils in Spain. Advances in Bioscience and Biotechnology, 9, 469-480.

https://doi.org/10.4236/abb.2018.99032

Received: March 26, 2018

Accepted: September 18, 2018

Published: September 21, 2018

Copyright $\odot 2018$ by authors and Scientific Research Publishing Inc. This work is licensed under the Creative Commons Attribution-NonCommercial International License (CC BY-NC 4.0). http://creativecommons.org/licenses/by-nc/4.0/

\begin{abstract}
Environmental dissemination of antimicrobial resistance genes may occur through agricultural residues, such as animal manure. We studied the resistome of 16 pool samples of animal manure (pig slurry $[\mathrm{n}=8]$ and poultry manure $[n=8]$ ), and 16 soil samples (manure-amended $[n=8]$ and nonmanure-amended $[\mathrm{n}=8])$. All samples were collected in central Spain. Detection was based on 18 selected antimicrobial resistance genes (ARGs). The most commonly detected genes in animal manure were sul1 (16/16), sul (16/16), $\operatorname{tet}(A)(16 / 16)$, aad $A(16 / 16), \operatorname{tet}(B)(15 / 16)$, and str $(15 / 16)$. Genes $b a_{\mathrm{TEM}}$ (7/8), mecA (6/8), vanA (5/8) and $q n r B(4 / 8)$ were more frequently detected in chicken manure, whereas pig slurry samples presented higher levels of $\operatorname{tet}(C)(8 / 8)$ and $\operatorname{tet}(M)(8 / 8)$. Out of the four genes selected for their clinical relevance, three- $b l a_{\text {CTX-M }}$, van $A$, and $m e c A$-were detected in animal manure. The $\operatorname{bla}_{a_{\text {Стх-м }}}(1 / 8)$ and $\operatorname{van} A(5 / 8)$ genes were only identified in chicken manure. To our knowledge, this is the first report of direct detection of $m e c A$ gene in poultry manure and pig slurry. Eleven out of 18 ARGs were detected in amended soil, while only genes suh (3/8) and str (2/8) were found in nonanthropogenically impacted soils (NAIS), supporting the hypothesis that ARGs may serve as indicators of "anthropogenic impact" on the environment.
\end{abstract}

\section{Keywords}

Antibiotic Resistance, $b l a_{\text {Стх-M }}$, mecA, Pig Slurry, van $A$

\section{Introduction}

Antimicrobial resistance is a rising health threat worldwide, for both humans 
and domestic animals [1]. An important resistance mechanism is the acquisition of antimicrobial resistance genes (ARGs) through spontaneous mutations or incorporation of ARGs from other bacteria [2]. ARGs are considered environmental pollutants and could be disseminated by horizontal gene transfer between bacterial species via mobile genetic elements, e.g. plasmids, integrons, transposons and transduction by bacteriophages [3] [4] [5]. These mobilizable genes, the "mobilome", include a collection of all genes that could contribute to a phenotype of antimicrobial resistance, the "resistome" [5].

Most antibiotics are developed from natural bioactive compounds produced by soil fungi or bacteria, and are an integral part of their ecological systems [6]. However, the composition of ARGs in soil has been under constant change since the antibiotic era [7] due to the use of antibiotics as therapeutic treatments and livestock feeding supplements, such as growth promoters. Although the use of growth promoters in animal production was banned in the member states of the European Union, including Spain, since 2006 [8], this practice is still active in many other countries. A significant amount of the antibiotics used in veterinary medicine (between $30 \%$ and $90 \%$ ) is excreted essentially unchanged [9]. As a result, antibiotic residues and ARGs may be disseminated in the environment through agricultural residues, such as animal manure, which can be used as agricultural fertilizer [10] [11]. The occurrence and potential environmental impact of antimicrobial resistant bacteria and ARGs in the environment are still poorly understood [12].

We evaluated the presence of selected ARGs in two types of commonly used agricultural amendments in Spain; pig slurry and poultry manure, and established the impact of such practices by comparing the presence of ARGs in pig slurry-amended and nonanthropogenically impacted soils (NAIS) in the country.

\section{Materials and Methods}

\subsection{Samples}

A total of 32 samples were collected in the central area of Spain from April 2012 to April 2014; 16 samples of manure from different broiler poultry and swine farms (poultry manure $[n=8]$ and pig slurry $[n=8]$ ), and 16 samples of soil (agricultural soil periodically amended with pig slurry $[n=8]$ and soil from the same region not amended in the last five years or more $[n=8]$ ). Each of the 32 samples consisted of six subsamples, pooled from each collection site. Manure samples were collected from storage tanks. Soil samples were collected at $5-10$ $\mathrm{cm}$ deep. Amended soil samples were collected at least 15 days after amendment with pig slurry, the most commonly used amendment in the studied area. Each sample of nonamended soil was collected approximately $10 \mathrm{~km}$ apart from the rest. We compared the presence of antibiotic resistance in poultry vs. pig slurry manure and amended soil vs. NAIS soils. The sample size was determined attending to logistics reasons, selecting those broiler poultry and swine farms that 
allowed the sampling operations.

\subsection{Real-Time PCR Detection of ARGs}

High Pure Template DNA (Roche Diagnostics, Mannheim, Germany) and E.Z.N.A ${ }^{\circledR}$ soil DNA kit (Promega, Madison, WI, USA) were used to extract DNA from poultry manure and pig slurry samples, and soil samples, respectively. The presence of $16 \mathrm{~S}$ rRNA gene and 18 selected ARGs was tested using real-time PCR (rtPCR); 18 of them based on $\mathrm{SYBR}^{\circledR}$ Green and one based on a TaqMan ${ }^{\circledR}$ probe (Table 1), all performed in an Eco Illumina thermocycler (Illumina, San Diego, CA, USA).

To study different profiles, we selected genes related to some of the initially most commonly used antibiotics (e.g., cat $A 1, \operatorname{cat} A 2, \operatorname{tet}(A), \operatorname{tet}(B), \operatorname{tet}(C)$, $\operatorname{tet}(M)$, $\operatorname{tet}(Q)$, sull, sul, str and aadA), the currently most commonly used antibiotics in poultry and swine production ( $\left.q n r B, q n r S, b a_{\mathrm{TEM}}\right)$, and selected antibiotics of clinical relevance ( $\operatorname{arm} A, b l a_{\mathrm{CTX}-\mathrm{M}}, \operatorname{mec} A$ and $\operatorname{van} A$, respectively responsible to aminoglycoside-, extended-spectrum $\beta$-lactamase-, methicillin- in Staphylococcus aureus and vancomycin-resistances). It was not possible to discriminate between $\operatorname{str} A-\operatorname{str} B$ genes or the different aad $A$ alleles. Gut microbiome samples previously tested as positive for the selected genes were selected as positive controls. Unfortunately, information regarding the antibiotics used in the studied animal farms was confidential.

The 16S rRNA gene (present in all bacteria) was used to check the samples' viability. A sample was considered validated when a 1/10 dilution of the purified DNA showed a cycle threshold less than 25. In addition, this gene was used to quantify the presence of the selected ARGs in different samples, establishing the relative concentration of the sul gene in comparison with the 16S rRNA gene, as follows: number of copies of sul gene per reaction/number of copies of $16 \mathrm{~S}$ rDNA gene. The sul gene was selected to perform the relative quantification of its presence because it was one of the two ARGs detected in NAIS. Standard controls for the 16S rRNA gene and the sul gene were established based on previously tested samples. Purified DNA fragments were cloned into a plasmid vector $\left(\mathrm{pGEM}^{\mathbb{B}}-\mathrm{T}\right.$, Promega, Madison, WI, USA) and purified for a second time (Wizard ${ }^{\circledR}$ Plus SV Minipreps DNA Purification System, Promega, Madison, WI, USA). Plasmid colonies were subcultured in LB medium supplemented with ampicillin. Total DNA was measured by a spectrophotometer. The estimated number of copies was obtained by dividing the absorbance value at $260 \mathrm{~nm}$ by the plasmid molecular weight (including the specific insert). Subsequently, ten-fold dilutions of quantified plasmids were evaluated by rtPCR to establish the detection limits of sul 2 and $16 \mathrm{~S}$ rRNA genes.

\subsection{Statistical Analysis}

Chi-square test was used to compare the occurrence of ARGs between samples of poultry manure and pig slurry, and pig slurry-amended soils and NAIS. Relative 
F. Esperón et al.

Table 1. Primers used for real time PCR detection of selected ARGs.

\begin{tabular}{|c|c|c|c|c|c|}
\hline Gene & Sequence $\left(5^{\prime}-3^{\prime}\right)$ & Function & Annealing temperature $\left({ }^{\circ} \mathrm{C}\right)$ & Amplicon size (bp) & Reference \\
\hline \multirow{3}{*}{$\operatorname{aad} A$} & F: GCAGCGCAATGACATTCTTG & $\mathrm{F}$ & \multirow{3}{*}{60} & \multirow{3}{*}{282} & \multirow{3}{*}{ [35] } \\
\hline & & & & & \\
\hline & R: ATCCTTCGGCGCGATTTTG & $\mathrm{R}$ & & & \\
\hline \multirow[b]{2}{*}{$\operatorname{arm} A$} & ATTCTGCCTATCCTAATTGG & $\mathrm{F}$ & \multirow[b]{2}{*}{55} & \multirow[b]{2}{*}{315} & \multirow[b]{2}{*}{ [36] } \\
\hline & ACCTATACTTTATCGTCGTC & $\mathrm{R}$ & & & \\
\hline \multirow{2}{*}{$b l a_{\mathrm{CTX}-\mathrm{M}}$} & TTTGCGAT GTGCAGTACCAGTAA & $\mathrm{F}$ & \multirow[b]{2}{*}{60} & \multirow[b]{2}{*}{591} & \multirow[b]{2}{*}[37]{} \\
\hline & CGATATCGTTGGTGGTGCCATA & $\mathrm{R}$ & & & \\
\hline \multirow{2}{*}{$b l a_{\mathrm{TEM}}$} & AAAGATGCTGAAGATCA & $\mathrm{F}$ & \multirow[b]{2}{*}{44} & \multirow[b]{2}{*}{425} & \multirow{2}{*}{ [38] } \\
\hline & TTTGGTATGGCTTCATTC & $\mathrm{R}$ & & & \\
\hline \multirow{2}{*}{ cat $A 1$} & GGTGATATGGGATAGTGTT & $\mathrm{F}$ & \multirow{2}{*}{60} & \multirow{2}{*}{349} & \multirow{7}{*}{ [40] } \\
\hline & CCATCACATACTGCATGATG & $\mathrm{R}$ & & & \\
\hline \multirow[b]{2}{*}{ cat $A 2$} & GATTGACCTGAATACCTGGAA & $\mathrm{F}$ & \multirow[b]{2}{*}{60} & \multirow[b]{2}{*}{567} & \\
\hline & CCATCACATACTGCATGATG & $\mathrm{R}$ & & & \\
\hline \multirow{3}{*}{$\operatorname{mec} A$} & CATTGATCGCAACGTTCAATTT & $\mathrm{F}$ & \multirow{3}{*}{60} & \multirow{3}{*}{99} & \\
\hline & TGGTCTTTCTGCATTCCTGGA & $\mathrm{R}$ & & & \\
\hline & TGGAAGTTAGATTGGGATCATAGCGTCAT & probe $^{\mathrm{a}}$ & & & \\
\hline$a n r R$ & GGMATHGAAATTCGCCACTG & $\mathrm{F}$ & 62 & 263 & \\
\hline QHIID & TTYGCBGYYCGCCAGTCGAA & $\mathrm{R}$ & 02 & 203 & \\
\hline & GACGTGCTAACTTGCGTGAT & $\mathrm{F}$ & & & {$[41]$} \\
\hline$q n r S$ & TGGCATTGTTGGAAACTTG & $\mathrm{R}$ & 62 & 118 & \\
\hline & GCGCTNTATGCGTTGATGCA & $\mathrm{F}$ & & & \\
\hline $\operatorname{tet}(A)$ & ACAGCCCGTCAGGAAATT & $\mathrm{R}$ & 62 & 387 & [42] \\
\hline & TACGTGAATTTATTGCTTCGG & $\mathrm{F}$ & & & \\
\hline $\operatorname{tet}(B)$ & ATACAGCATCCAAAGCGCAC & $\mathrm{R}$ & 60 & 206 & {$[43]$} \\
\hline & CTTGAGAGCCTTCAACCCAG & $\mathrm{F}$ & & & \\
\hline $\operatorname{tet}(C)$ & ATGGTCGTCATCTACCTGCC & $\mathrm{R}$ & 66 & 418 & \\
\hline & ACAGAAAGCTTATTATATAAC & $\mathrm{F}$ & & & {$[44]$} \\
\hline $\operatorname{tet}(M)$ & TGGCGTGTCTATGATGTTCAC & $\mathrm{R}$ & 60 & 171 & \\
\hline $\operatorname{tet}(O)$ & AGAATCTGCTGTTTGCCAGTG & $\mathrm{F}$ & 63 & 160 & [15] \\
\hline $\operatorname{tet}(Q)$ & CGGAGTGTCAATGATATTGCA & $\mathrm{R}$ & 63 & 169 & [45] \\
\hline str & AATGAGTTTTGGAGTGTCTCAACGTA & $\mathrm{F}$ & 60 & 147 & {$[46]$} \\
\hline 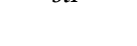 & AATCAAAACCССТATTAAAGCCAAT & $\mathrm{R}$ & & & \\
\hline sul & CGCACCGGAAACATCGCTGCAC & $\mathrm{F}$ & & & \\
\hline $\sin 1$ & TGAAGTTCCGCCGCAAGGCTCG & $\mathrm{R}$ & 63 & 163 & \\
\hline$s^{2} h$ & TCCGGTGGAGGCCGGTATCTGG & $\mathrm{F}$ & $6^{2}+2$ & & [47] \\
\hline SUIL & CGGGAATGCCATCTGCCTTGAG & $\mathrm{R}$ & 63 & 191 & \\
\hline $\operatorname{Van} A$ & GAAATCAACCATGTTGATGTAGCA & $\mathrm{F}$ & 61 & 572 & {$[48]$} \\
\hline Vanth & TTTGCCGTTTCCTGTATCCGT & $\mathrm{R}$ & 01 & $3 / 2$ & {$[40]$} \\
\hline 16S rDNA & ATGGCTGTCGTCAGCT & $\mathrm{F}$ & & 352 & {$[40]$} \\
\hline 165 rDNA & ACGGGCGGTGTGTAC & $\mathrm{R}$ & 62 & 352 & [49] \\
\hline
\end{tabular}

'TaqMan probes: 5' (6FAM); 3' (nonfluorescent quencher). $\mathrm{F}=$ Forward, $\mathrm{R}=$ Reverse. 
quantification (number of copies of ARG/number of copies of $16 \mathrm{~S}$ rDNA) and the mean number of genes per sample among all four categories were evaluated by the Mann-Whitney $U$ test. All statistical studies were performed with the aid of SPSS 15.0 software. Statistical significance for all tests was defined as $P<0.05$.

\section{Results and Discussion}

Results are summarized in Table 2. Out of the 18 ARGs analyzed in this study, 16 were detected. The presence of $\operatorname{arm} A$ and cat $A 2$ was below the detection limits.

\subsection{Poultry Manure vs. Pig Slurry}

Statistically significant differences were detected between poultry manure and pig slurry in relation to the mean number of ARGs present in the samples ( $P=$ $0.013) ; \operatorname{mec} A(P=0.012), \operatorname{van} A(P=0.007), q n r B(P=0.021)$, and $b a_{\mathrm{TEM}}(P=$ $0.000)$ genes were found more frequently in poultry manure, while $\operatorname{tet}(C)(P=$

Table 2. Selected ARGs tested by real time PCR, relative amount of suh gene, and mean number of genes per sample.

\begin{tabular}{|c|c|c|c|c|}
\hline Gene & Poultry manure & Pig slurry & Amended soil & NAIS \\
\hline $\operatorname{aad} A$ & $8 / 8$ & $8 / 8$ & $4 / 8$ & $0 / 8$ \\
\hline $\operatorname{arm} A$ & $0 / 8$ & $0 / 8$ & $0 / 8$ & $0 / 8$ \\
\hline$b l a_{\mathrm{CTX}-\mathrm{M}}$ & $1 / 8$ & $0 / 8$ & $0 / 8$ & $0 / 8$ \\
\hline$b l a_{\mathrm{TEM}}$ & $7 / 8$ & $0 / 8$ & $3 / 8$ & $0 / 8$ \\
\hline cat $A 1$ & $3 / 8$ & $1 / 8$ & $0 / 8$ & $0 / 8$ \\
\hline catA2 & $0 / 8$ & $0 / 8$ & $0 / 8$ & $0 / 8$ \\
\hline $\operatorname{mec} A$ & $6 / 8$ & $1 / 8$ & $0 / 8$ & $0 / 8$ \\
\hline$q n r B$ & $4 / 8$ & $0 / 8$ & $0 / 8$ & $0 / 8$ \\
\hline$q n r S$ & $6 / 8$ & $3 / 8$ & $3 / 8$ & $0 / 8$ \\
\hline str & $8 / 8$ & $7 / 8$ & $4 / 8$ & $2 / 8$ \\
\hline sull & $8 / 8$ & $8 / 8$ & $5 / 8$ & $0 / 8$ \\
\hline sul 2 & $8 / 8$ & $8 / 8$ & $8 / 8$ & $3 / 8$ \\
\hline sul $\left(\right.$ relative $\left.^{\mathrm{a}}\right)$ & $\begin{array}{c}6.2 \times 10^{-3} \\
\left(1.2 \times 10^{-6}-2.6 \times 10^{-2}\right)\end{array}$ & $\begin{array}{c}5.1 \times 10^{-2} \\
\left(1.4 \times 10^{-2}-8.8 \times 10^{-2}\right)\end{array}$ & $\begin{array}{c}9.8 \times 10^{-4} \\
\left(1.7 \times 10^{-4}-2.0 \times 10^{-3}\right)\end{array}$ & $\begin{array}{c}0.3 \times 10^{-4} \\
\left(0.8 \times 10^{-6}-0.7 \times 10^{-4}\right)\end{array}$ \\
\hline $\operatorname{tet}(A)$ & $8 / 8$ & $8 / 8$ & $3 / 8$ & $0 / 8$ \\
\hline $\operatorname{tet}(B)$ & $7 / 8$ & $8 / 8$ & $3 / 8$ & $0 / 8$ \\
\hline $\operatorname{tet}(C)$ & $3 / 8$ & $8 / 8$ & $3 / 8$ & $0 / 8$ \\
\hline $\operatorname{tet}(M)$ & $4 / 8$ & $8 / 8$ & $1 / 8$ & $0 / 8$ \\
\hline $\operatorname{tet}(Q)$ & $7 / 8$ & $7 / 8$ & $5 / 8$ & $0 / 8$ \\
\hline $\operatorname{van} A$ & $5 / 8$ & $0 / 8$ & $0 / 8$ & $0 / 8$ \\
\hline $\begin{array}{l}\text { Mean number of } \\
\text { genes/sample }\end{array}$ & $\begin{array}{c}11.6 \\
(9-14)\end{array}$ & $\begin{array}{c}9.4 \\
(8-11)\end{array}$ & $\begin{array}{c}5.2 \\
(1-10)\end{array}$ & $\begin{array}{c}0.6 \\
(0-2)\end{array}$ \\
\hline
\end{tabular}

${ }^{\mathrm{a} C a l c u l a t e d}$ as follows: number of copies of ARG per reaction/number of copies of $16 \mathrm{~S}$ rDNA gene. 
$0.007)$ and $\operatorname{tet}(M)(P=0.021)$ ARGs were more frequently found in pig than in poultry slurry.

The most commonly detected ARGs in animal manure samples were tet $(A)$ (16/16), sul1 (16/16), suh (16/16), aadA (16/16), tet(B) (15/16) and str (15/16), all related to some of the initially most commonly used antibiotics. Efflux pump genes- $\operatorname{tet}(A)$ and $\operatorname{tet}(B)$ - were present in almost all the animal manure samples ( $8 / 8$ and $8 / 8$ in pig slurry samples and $8 / 8$ and $7 / 8$ in poultry manure, respectively). The ribosomal protection protein gene $\operatorname{tet}(M)$ and the tetracycline efflux pump gene tet $(C)$ were more frequently found in pig than in poultry manure, whereas $\operatorname{tet}(Q)$ was more frequent in both poultry manure and pig slurry samples. Based on our findings, pig slurry may be considered a major source of tet genes, followed by poultry manure. Our findings partially agree with Cheng et al. [13], who reported tet and sul genes as the most frequently detected ARGs in animal manure.

Genes able to confer resistance to streptomycin-str and aadA- [14] and spectinomycin-aadA- [15] were detected in poultry manure and pig slurry. The presence of str genes and aadA in $E$. coli from poultry manure and pig slurry was previously reported [16].

The gene cat $A 1$ was present in four out of 16 samples of animal origin (poultry manure [3/8] and pig slurry [1/8]). None of the samples presented the cat $A 2$ gene. Interestingly, the use of chloramphenicol in food-producing animals has been banned in the EU since 1994 [17]. The presence of cat $A 1$ in the absence of chloramphenicol residues to induce selective pressure has been attributed to its relationship with other plasmid-mediated ARGs [18]. Bacterial isolation was not performed in this study; therefore, we were not able to determine if different ARGs were present in the same isolate. However, we found that all cat positive samples were also positive for sull and $s u h$, which is in agreement with previously published reports [19].

Regarding quinolone resistance genes, $q n r S$ was present in pig slurry samples (3/8) and highly prevalent in poultry manure (6/8), while $q n r B$ was only detected in poultry manure samples (4/8). The presence of $q n r$ genes in poultry products is well documented, but our prevalence is considerably higher than those previously published: $3.9 \%$ and $0.9 \%$ for $q n r B ; 5.1 \%$ and $8.11 \%$ for $q n r S$, respectively [20] [21], probably due to our methodology, more sensitive than previously culture-based studies [20] [21]. Thus, the real prevalence of $q n r$ genes could be higher than expected.

Beta-lactamase genes $b a_{\mathrm{TEM}}$ and $b l a_{\mathrm{CTX}-\mathrm{M}}$, were detected in poultry manure$7 / 8$ and $1 / 8$, respectively-but not in pig slurry. These genes are related to extended-spectrum beta-lactamases (ESBLs), important Enterobacteriaceae resistance mechanisms against cephalosporins [22]. CTX-M-type resistance genes have replaced other families, such as TEM and SHV, emerging all over the world [23]. The presence of $b l a_{\text {CTX-M }}$ gene in $E$. coli isolated from poultry manure has been previously reported [16]. All pig slurry samples were negative, although 
other studies have isolated E. coli with $b a_{\mathrm{TEM}}$ and $b a_{\mathrm{CTX}}$ from pig slurry [16].

Vancomycin resistance gene ( $\operatorname{Van} A)$ was only detected in poultry manure $(5 / 8)$. Vancomycin-resistant enterococci have been related to the use of avoparcin, which was the first growth promoter used in food-producing animals banned by the European Union, in 1997 [24] [25]. After an initial decline, the presence of vanA gene seems to persist in poultry [26] [27], and based on our results, is still widely present in poultry manure.

The high prevalence of mecA gene, linked to methicillin resistant Staphylococcus aureus (MRSA), was noteworthy in chicken manure samples (6/8). This gene was also detected in one sample of pig slurry (1/8). To our knowledge, this is the first report of mecA gene direct detection in poultry manure and pig slurry. Colomer-Lluch et al. found the mecA gene in fecal waste samples from slaughterhouses, suggesting its transport by bacteriophages and linking it to bacteria affecting avian and swine species [28].

\subsection{Amended Soil vs. NAIS}

There were statistically significant differences between amended and no-amended soils regarding the presence of $\operatorname{sul}, \operatorname{suh}$, $\operatorname{tet}(Q)$, and $\operatorname{aad} A(P=0.007, P=0.007$, $P=0.007$ and $P=0.021$, respectively); the relative concentration of $\operatorname{sul}(P=$ $0.014)$, and the mean number of ARGs per sample $(P=0.009)$. The presence of ARGs was higher in amended soils, as well as the relative concentration of suh, showing that these genes are probably derived from human activities, as observed by Pruden et al. [29].

Eleven different ARGs were present in at least one manure amended soil sample: all sul and tet genes, $b a_{\mathrm{TEM}}, q n r S$, aadA and str genes. On the other hand, only suh and str genes were found in NAIS (3/8 and 2/8, respectively). No soil samples presented the genes selected by their clinical relevance ( $\operatorname{arm} A, b l a_{\mathrm{CTX}-\mathrm{M}}$, $\operatorname{mec} A$, and $\operatorname{van} A)$. Our results differ from previous studies that detected several ARGs in both natural and anthropogenically impacted environments [29] [30].

Gene $\operatorname{bla}_{\mathrm{TEM}}(3 / 8)$ and $q n r S$ (3/8), related to antibiotics frequently found in swine production, were detected in pig slurry amended soil, but $q n r B$ gene was not detected in this study. The presence of $b l a_{\mathrm{TEM}}$ in this type of soil was observed by Binh et al. [31], while qnrS gene has been previously detected in other anthopogenically impacted soils, like soils irrigated with wastewater [32].

We amplified the str gene in both amended soils and NAIS, and aad $A$ only in amended soils. Both genes, str and aadA, have been detected in antic soil samples from the Siberian permafrost [33], previous to the antibiotic era, so these elements could be related to other factors beside the modern use of antibiotics.

The sul gene was found in amended and nonamended soils, but its relative concentration was significantly higher in amended soil samples. The relative concentration of suh gene in agricultural soils presented the same order of magnitude as previously published [34]. It is important to remark that this gene is considered the most sensible indicator of anthropogenic/agricultural impact 
[29].

Our findings demonstrate that agricultural activities may contribute significantly to the environmental spread of $\operatorname{aad} A, \operatorname{sul} 1, \operatorname{sul} 2$, and $\operatorname{tet}(Q)$ through the use of pig slurry to amend agricultural soils. Although not significant, the presence of other tet genes, $b a_{\mathrm{TEM}}$ and $q n r S$ seem to be higher in those soils amended with pig slurry. In addition, amended soils presented higher mean ARGs number per sample than NAIS.

As a consequence, in despite of the impossibility to determine the individual bacterial ARGs due to the lack of culture and subsequent isolation, it is possible to obtain specific patterns of anthropogenic and nonanthropogenic environments based on ARG profiles and concentrations.

\subsection{Conclusion}

Animal waste carries ARGs, some of clinical relevance ( $\operatorname{van} A, \operatorname{mec} A$, and $b l_{\mathrm{CTX}-\mathrm{M}}$ ), which may be spread to the environment through the use of animal manure to amend agricultural soils. This is the first report of direct detection of mec $A$ in poultry manure and pig slurry. Despite the limited sample size and number of ARGs we studied, our results show the impact of anthropogenic activities on the environment through the detection of several ARGs, e.g., sull, bla $a_{\mathrm{TEM}}$ and qnrS, in manure-amended agricultural soils, while the same ARGs were below the detection limit in NAIS. Our results support the hypothesis that the detection and quantification of ARGs may serve as indicators of the "anthropogenic impact" on the environment and propose the development of specific ARG profiles of these pollutants to compare different environmental scenarios. Further studies, focusing on the consequences of anthropogenic activities on microbial populations in different scenarios are needed to elucidate the real impact of ARGs.

\section{Acknowledgements}

We thank Veronica Nogal, Elena Neves and Ana Carolina Ewbank for their technical assistance and support. The authors declare they have no conflict of interest. This study was supported by the National Institute for Agricultural and Food Research and Technology [RTA2014-00012-C03-02 and RTA2010-00066-C02-01] and the Government of the Region of Madrid [CAM S2013/ABI-2747].

\section{Conflicts of Interest}

The authors declare no conflicts of interest regarding the publication of this paper.

\section{References}

[1] Bush, K., Courvalin, P., Dantas, G., Davies, J., Eisenstein, B., Huovinen, P., et al. (2011) Tackling Antibiotic Resistance. Nature Reviews Microbiology, 9, 894-896. https://doi.org/10.1038/nrmicro2693

[2] Lupo, A., Coyne, S. and Berendonk, T.U. (2012) Origin and Evolution of Antibiotic 
Resistance: The Common Mechanisms of Emergence and Spread in Water Bodies. Frontiers in Microbiology, 3, 18. https://doi.org/10.3389/fmicb.2012.00018

[3] Zhu, Y.G., Johnson, T.A., Su, J.Q., Qiao, M., Guo, G.X., Stedtfeld, R.D., et al. (2013) Diverse and Abundant Antibiotic Resistance Genes in Chinese Swine Farms. Proceedings of the National Academy of Sciences of the United States of America, 110, 3435-3440. https://doi.org/10.1073/pnas.1222743110

[4] Davies, J. and Davies, D. (2010) Origins and Evolution of Antibiotic Resistance. Microbiology and Molecular Biology Reviews, 74, 417-433. https://doi.org/10.1128/MMBR.00016-10

[5] Rolain, J.M., Fancello, L., Desnues, C. and Raoult, D. (2011) Bacteriophages as Vehicles of the Resistome in Cystic Fibrosis. Journal of Antimicrobial Chemotherapy, 66, 2444-2447. https://doi.org/10.1093/jac/dkr318

[6] Blaser, M.J. and Falkow, S. (2009) What Are the Consequences of the Disappearing Human Microbiota? Nature Reviews Microbiology, 7, 887-894. https://doi.org/10.1038/nrmicro2245

[7] Gillings, M.R. (2013) Evolutionary Consequences of Antibiotic Use for the Resistome, Mobilome and Microbial Pangenome. Frontiers in Microbiology, 4, 4. https://doi.org/10.3389/fmicb.2013.00004

[8] European Commission (2003) Regulation EC No 1831/2003 of the European Parliament and Council of 22 Septeber 2003 on Additives for Use in Animal Nutrition. Official Journal of the European Union, L268, 29-43.

[9] Sarmah, A.K., Meyer, M.T. and Boxall, A.B.A. (2006) A Global Perspective on the Use, Sales, Exposure Pathways, Occurrence, Fate and Effects of Veterinary Antibiotics (VAs) in the Environment. Chemosphere, 65, 725-759. https://doi.org/10.1016/j.chemosphere.2006.03.026

[10] Heuer, H., Schmitt, H. and Smalla, K. (2011) Antibiotic Resistance Gene Spread Due to Manure Application on Agricultural Fields. Current Opinion in Microbiology, 14, 236-243. https://doi.org/10.1016/j.mib.2011.04.009

[11] Binh, C.T., Heuer, H., Kaupenjohann, M. and Smalla, K. (2008) Piggery Manure Used for Soil Fertilization Is a Reservoir for Transferable Antibiotic Resistance Plasmids. FEMS Microbiology Ecology, 66, 25-37. https://doi.org/10.1111/j.1574-6941.2008.00526.x

[12] Martínez, J.L. (2008) Antibiotics and Antibiotic Resistance Genes in Natural Environments. Science, 321, 365-367. https://doi.org/10.1126/science.1159483

[13] Cheng, W., Chen, H., Su, C. and Yan, S. (2013) Abundance and Persistence of Antibiotic Resistance Genes in Livestock Farms: A Comprehensive Investigation in Eastern China. Environment International, 61, 1-7. https://doi.org/10.1016/j.envint.2013.08.023

[14] Shaw, K.J., Rather, P.R., Hare, R.S. and Miller, G.H. (1993) Molecular Genetics of Aminoglycoside Resistance Genes and Familial Relationships of the Aminoglycoside-Modifying Enzymes. Microbiological Reviews, 57, 138-163.

[15] Fluit, A.C. and Schmitz, F.J. (2004) Resistance Integrons and Super-Integrons. Clinical Microbiology and Infection, 10, e272-e288.

[16] Adelowo, O.O., Fagade, O.E. and Agersø, Y. (2014) Antibiotic Resistance and Resistance Genes in Escherichia coli from Poultry Farms, Southwest Nigeria. The Journal of Infection in Developing Countries, 8, 1103-1112. https://doi.org/10.3855/jidc.4222

[17] Commission of the European Communities (1994) Amending Annexes I, II, III and 
IV of Council Regulation No. 2377/90 Laying down a Community Procedure for the Establishment of Maximum Residue Limits of Veterinary Medicinal Products in Foodstuffs of Animal Origin. Official Journal of the European Communities, 156, 6-7.

[18] Chen, S., Zhao, S., White, D.G., Schroeder, C.M., Lu, R., Yang, H., et al. (2004) Characterization of Multiple-Antimicrobial-Resistant Salmonella Serovars Isolated from Retail Meats. Applied and Environmental Microbiology, 70, 1-7. https://doi.org/10.1128/AEM.70.1.1-7.2004

[19] Gow, S.P., Waldner, C.L., Harel, J. and Boerlin, P. (2008) Associations between Antimicrobial Resistance Genes in Fecal Generic Escherichia coli Isolates from Cow-Calf Herds in Western Canada. Applied and Environmental Microbiology, 74, 3658-3666. https://doi.org/10.1128/AEM.02505-07

[20] Huang, S.Y., Dai, L., Xia, L.N., Du, X.D., Qi, Y.H., Liu, H.B., et al. (2009) Increased Prevalence of Plasmid-Mediated Quinolone Resistance Determinants in Chicken Escherichia coli Isolates from 2001 to 2007. Foodborne Pathogens and Disease, 6, 1203-1209. https://doi.org/10.1089/fpd.2009.0348

[21] Xie, R., Huo, S., Li, Y., Chen, L., Zhang, F. and Wu, X. (2014) Molecular Epidemiological Survey on Quinolone Resistance Genotype and Phenotype of Escherichia coli in Septicemic Broilers in Hebei, China. Poultry Science, 93, 335-339. https://doi.org/10.3382/ps.2013-03522

[22] Coque, T.M., Baquero, F. and Cantón, R. (2008) Increasing Prevalence of ESBLProducing Enterobacteriaceae in Europe. Eurosurveillance, 13, pii: 19044.

[23] Bonnet, R. (2004) Growing Group of Extended-Spectrum Beta-Lactamases: The CTX-M Enzymes. Antimicrobial Agents and Chemotherapy, 48, 1-14. https://doi.org/10.1128/AAC.48.1.1-14.2004

[24] Mudd, A. (1996) Vancomycin Resistance and Avoparcin. The Lancet, 347, 1412. https://doi.org/10.1016/S0140-6736(96)91055-7

[25] European Commission (1997) Commission Directive 97/6/EC. Official Journal of the European Communities, 35, 11-13.

[26] Klare, I., Badstübner, D., Konstabel, C., Böhme, G., Claus, H. and Witte, W. (1999) Decreased Incidence of vanA-Type Vancomycin-Resistant Enterococci Isolated from Poultry Meat and from Fecal Samples of Humans in the Community after Discontinuation of Avoparcin Usage in Animal Husbandry. Microbial Drug Resistance, 5, 45-52. https://doi.org/10.1089/mdr.1999.5.45

[27] Tzavaras, I., Siarkou, V.I., Zdragas, A., Kotzamanidisa, C., Vafeas, G., Bourtzi-Hatzopoulou, E., et al. (2012) Diversity of vanA-Type Vancomycin-Resistant Enterococcus faecium Isolated from Broilers, Poultry Slaughterers and Hospitalized Humans in Greece. Journal of Antimicrobial Chemotherapy, 67, 1811-1818. https://doi.org/10.1093/jac/dks166

[28] Colomer-Lluch, M., Imamovic, L., Jofre, J. and Muniesa, M. (2011) Bacteriophages Carrying Antibiotic Resistance Genes in Fecal Waste from Cattle, Pigs, and Poultry. Antimicrobial Agents and Chemotherapy, 55, 4908-4911. https://doi.org/10.1128/AAC.00535-11

[29] Pruden, A., Pei, R., Storteboom, H. and Carlson, K.H. (2006) Antibiotic Resistance Genes as Emerging Contaminants: Studies in Northern Colorado. Environmental Science \& Technology, 40, 7445-7450. https://doi.org/10.1021/es0604131

[30] Yang, H., Byelashov, O.A., Geornaras, I., Goodridge, L.D., Nightingale, K.K., Belk, K.E., et al. (2010) Presence of Antibiotic-Resistant Commensal Bacteria in Samples from Agricultural, City, and National Park Environments Evaluated by Standard 
Culture and Real-Time PCR Methods. Canadian Journal of Microbiology, 56, 761-770. https://doi.org/10.1139/W10-060

[31] Binh, C.T.T., Heuer, H., Gomes, N.C., Kotzerke, A., Fulle, M., Wilke, B.M., et al. (2007) Short-Term Effects of Amoxicillin on Bacterial Communities in Manured Soil. FEMS Microbiology Ecology, 62, 290-302. https://doi.org/10.1111/j.1574-6941.2007.00393.x

[32] Dalkmann, P., Broszat, M., Siebe, C., Willaschek, E., Sakinc, T., Huebner, J., et al. (2012) Accumulation of Pharmaceuticals, Enterococcus, and Resistance Genes in Soils Irrigated with Wastewater for Zero to 100 Years in Central Mexico. PLoS ONE, 7, e45397. https://doi.org/10.1371/journal.pone.0045397

[33] Mindlin, S.Z., Soina, V.S., Petrova, M.A. and Gorlenko, Zh.M. (2008) Isolation of Antibiotic Resistance Bacterial Strains from Eastern Siberia Permafrost Sediments. Russian Journal of Genetics, 44, 27-34. https://doi.org/10.1134/S1022795408010043

[34] Ji, X., Shen, Q., Liu, F., Ma, J., Xu, G., Wang, Y., et al. (2012) Antibiotic Resistance Gene Abundances Associated with Antibiotics and Heavy Metals in Animal Manures and Agricultural Soils Adjacent to Feedlots in Shanghai, China. Journal of Hazardous Materials, 235-236, 178-185.

https://doi.org/10.1016/j.jhazmat.2012.07.040

[35] Devarajan, N., Laffite, A., Mulaji, C.K., Otamonga, J.P., Mpiana, P.T., Mubedi, J.I., et al. (2016) Occurrence of Antibiotic Resistance Genes and Bacterial Markers in a Tropical River Receiving Hospital and Urban Wastewaters. PLOS ONE, 11, e0149211. https://doi.org/10.1371/journal.pone.0149211

[36] Doi, Y. and Arakawa, Y. (2007) 16S Ribosomal RNA Methylation: Emerging Resistance Mechanism against Aminoglycosides. Clinical Infectious Diseases, 45, 88-94. https://doi.org/10.1086/518605

[37] Edelstein, M., Pimkin, M., Dmitrachenko, T., Semenov, V., Kozlova, N., Gladin, D., et al. (2004) Multiple Outbreaks of Nosocomial Salmonellosis in Russia and Belarus Caused by a Single Clone of Salmonella enterica Serovar Typhimurium Producing an Extended-Spectrum Beta-Lactamase. Antimicrobial Agents and Chemotherapy, 48, 2808-2815. https://doi.org/10.1128/AAC.48.8.2808-2815.2004

[38] Speldooren, V., Heym, B., Labia, R. and Nicolas-Chanoine, M.H. (1998) Discriminatory Detection of Inhibitor-Resistant Beta-Lactamases in Escherichia coli by Single-Strand Conformation Polymorphism-PCR. Antimicrobial Agents and Chemotherapy, 42, 879-884.

[39] Yoo, M.H., Huh, M.D., Kim, E., Lee, H.H. and Do Jeong, H. (2003) Characterization of Chloramphenicol Acetyltransferase Gene by Multiplex Polymerase Chain Reaction in Multidrug-Resistant Strains Isolated from Aquatic Environments. Aquaculture, 217, 11-21. https://doi.org/10.1016/S0044-8486(02)00169-2

[40] Francois, P., Pittet, D., Bento, M., Pepey, B., Vaudaux, P., Lew, D., et al. (2003) Rapid Detection of Methicillin-Resistant Staphylococcus aureus Directly from Sterile or Nonsterile Clinical Samples by a New Molecular Assay. Journal of Clinical Microbiology, 41, 254-260. https://doi.org/10.1128/JCM.41.1.254-260.2003

[41] Marti, E. and Balcazar, J.L. (2013) Real-Time PCR Assays for Quantification of qnr Genes in Environmental Water Samples and Chicken Feces. Applied and Environmental Microbiology, 79, 1743-1745. https://doi.org/10.1128/AEM.03409-12

[42] Jun, L.J., Jeong. J.B.; Huh, M.D., Chung, J.K., Choi, D.L., Lee, C.H., et al. (2004) Detection of Tetracycline-Resistance Determinants by Multiplex Polymerase Chain Reaction in Edwardsiella tarda Isolated from Fish Farms in Korea. Aquaculture, 240, 89-100. https://doi.org/10.1016/j.aquaculture.2004.07.025 
[43] Aminov, R.I., Chee-Sanford, J.C., Garrigues, N., Teferedegne, B., Krapac, I.J., White, B.A., et al. (2002) Development, Validation, and Application of PCR Primers for Detection of Tetracycline Efflux Genes of Gram-Negative Bacteria. Applied and Environmental Microbiology, 68, 1786-1793. https://doi.org/10.1128/AEM.68.4.1786-1793.2002

[44] Ng, L.K., Martin, I., Alfa, M. and Mulvey, M. (2001) Multiplex PCR for the Detection of Tetracycline Resistant Genes. Molecular and Cellular Probes, 15, 209-215. https://doi.org/10.1006/mcpr.2001.0363

[45] Aminov, R.I., Garrigues-Jeanjean, N. and Mackie, R.I. (2001) Molecular Ecology of Tetracycline Resistance: Development and Validation of Primers for Detection of Tetracycline Resistance Genes Encoding Ribosomal Protection Proteins. Applied and Environmental Microbiology, 67, 22-32. https://doi.org/10.1128/AEM.67.1.22-32.2001

[46] Wang, F.H., Qiao, M., Su, J.Q., Chen, Z., Zhou, X. and Zhu, Y.G. (2014) High Throughput Profiling of Antibiotic Resistance Genes in Urban Park Soils with Reclaimed Water Irrigation. Environmental Science \& Technology, 48, 9079-9085. https://doi.org/10.1021/es502615e

[47] Pei, R., Kim, S.C., Carlson, K.H. and Pruden, A. (2006) Effect of River Landscape on the Sediment Concentrations of Antibiotics and Corresponding Antibiotic Resistance Genes (ARG). Water Research, 40, 2427-2435. https://doi.org/10.1016/j.watres.2006.04.017

[48] Böckelmann, U., Dörries, H.H., Ayuso-Gabella, M.N., Salgot de Marçay, M., Tandoi, V., Levantesi, C., et al. (2009) Quantitative PCR Monitoring of Antibiotic Resistance Genes and Bacterial Pathogens in Three European Artificial Groundwater Recharge Systems. Applied and Environmental Microbiology, 75, 154-163. https://doi.org/10.1128/AEM.01649-08

[49] Peak, N., Knapp, C.W., Yang, R.K., Hanfelt, M.M., Smith, M.S., Aga, D.S., et al. (2007) Abundance of Six Tetracycline Resistance Genes in Wastewater Lagoons at Cattle Feedlots with Different Antibiotic Use Strategies. Environmental Microbiology, 9, 143-151. https://doi.org/10.1111/j.1462-2920.2006.01123.x 